\title{
Analysis of the Substantive and Procedural Elements of the Principle of Legality
}

\author{
Dr. Saimir Fekolli \\ Bledar Biti (Msc.) \\ Lecturer at “Aleksandër MOISIU” University Durrës, Albania \\ Francesk Ganaj (Msc.) \\ Candidate Prosecutor, Albania
}

Doi:10.19044/esj.2019.v15n5p254～URL:http://dx.doi.org/10.19044/esj.2019.v15n5p254

\begin{abstract}
The law, in general, and more specifically the criminal law is guided by some basic principles. One of the principles, which is most important, is the principle of legality which represents the criminal discipline regarding the abolition of the retrospective power of the unfavorable norm. This can also be considered as the bad retrospective power. This paper focuses on analyzing this principle in the doctrinal aspect. The analysis focuses on how the principle of legality is enforced and interpreted on International Law and Albanian Criminal Law. This paper also aims to analyze different decisions of the European Court of Justice and Constitutional Court of Albania to find out the effect of this principle.
\end{abstract}

Keywords: Principle of Legality, Criminal Law, Magna Carta Libertatum, European Court of Human Rights (ECHR) effective defense

\section{GENERAL ASPECTS OF THE PRINCIPLE OF LEGALITY}

The principle of legality generally acts as a "conditional principle for the executive body in the execution of its functions", which can also be applied in the criminal law. This principle is a doctrinal-based principle, which nowadays is placed in the sections of the modern and democratic judicial order. This is based on the State of Law and it manages to fix every State's action. This can act as a "criminal power" (potestapenale), its autonomous power, or as the State's Sovereign interpretation (Ramacci, 1991). In the field of the Criminal Law, the principle of legality has been accepted and expressed as a judicial norm, which is applicable before the action is taken; so it must be in force the moment a person commits a specific action (Carlassare, 1990).

The principle of legality in criminal law now constitutes an inevitable principle in our judicial culture, which can be defined as an absolute and 
undeniable element in the determination of criminal offenses, in the expression of the principle of taxation, non-admission of retrospective power, its clarity in describing the typical fact entered into force before performing the action, not allowing the analogy, etc. In a modern and guaranteed system of criminal law, the principle of legality is undoubtedly placed in an apical position in relation to all principles and other legal values which are already part of the constitutional provisions. This principle is mostly theoretical and political rather than criminal. Its review is expressed in the doctrine of the "social contract" alongside the review provided by the "Magna Carta Libertatum” (Fiandaca \& Musco, 2001).

Furthermore, some authors affirm this principle through the interpretation of the "Magna Carta Libertatum" established in 1215 which has more procedural rather than substantive guarantees (Islami, Hoxha, \& Panda, 2011). In the meantime, its evolution and development were made possible by the XVIII-XVIII century enlightened lawyer-philosophers, who evidenced the existence of fundamental rights and freedoms for individuals and their separation from State's power. The latter had to necessarily exercise its function in the respect of the rights and freedoms in maintaining a proportional relationship (the principle of proportionality) between the undertaken measure and its purpose.

Despite this, the followers that elaborated the principle of legality place the existence of the judge that is detached from the executive power at the very top. This is because, according to them, this kind of judge acts only according to the laws and elaborate the idea that the protection of the human rights can be achieved through the abolition of the retrospective power in the judicial norms. This is in respect to the principle of legal certainty based on the formula $x$ (action), $y$ (consequence) in which the act is punishable if it was illegal at the time it was committed (Montavani, 1992). The purpose of such a principle is to prohibit the arbitrary penalties for acts committed before the act was foreseen by the law. Thus, such elements have found formal recognition in addition to the constitutions of different countries, even in the "Universal Declaration of Human Rights and Citizens" of 1789, where the guarantee function comes from "predictability of the fact by law before the time of action". Judicially speaking, the principle of legality is a manifestation of the famous roman expression "nullum crimen nulla poena sine lege" which was later elaborated by the famous German criminal lawyer, Anslem Feuerbach. He emphasized that if we want to denounce someone criminally, it is important for that person to have some knowledge about the law in order for him to know the kind of offences that are punishable, and executing such offences could bring some negative judicial effects (Fiandaca \& Musco, 2001).

It is worth mentioning that the principle of legality is not only the manifestation of the obligation of the State power (its first meaning) to respect 
the rights of the citizens in exercising their rights, and to punish acts provided that they are foreseen as criminal facts, but it goes even further to play a preventive role. This is viewed in the spirit of elaboration made by Feuerbach who stated that the citizen should be known with the incriminating norm, which results in a preventive role fearful from punishment (Grasso, 1972). With such an elaboration, the principle of legality (or of the legal backup) finds an excuse in scientific terms of nature within the criminal system, and it is fully in line with the elaboration of the principle by the liberalist Democrats and the one made by Feuerbach. It is worth mentioning that with this formula, we can have a reference in "having the monopoly of the legislature in the selection of punishable facts and the sanctions to be applied" (Giovagnoli, 2008). However, this monopoly shall not be considered as an unconditional power, but instead it must be considered as a power that is conditioned by the obligation of the legislature in determining the facts and the respective penalties. Its obligation in decriminalizing or abolishing criminal offences, procedurally speaking, cannot be scientifically proven. This is also the case of its obligation to determine the preventability of the application of the "malam partem" analogy. In the modern criminal law, in respect to the principle of legality or to the legal reserve, the analogy is prohibited to be applied when the position of the defendant is deteriorating which is also known as "malam partem". This is a rule, and as such there is an exception, in the sense that it is permissible to apply analogy in cases when its application is favored by the defendant. This is otherwise known as the application of analogy to "in bonam partem".

\section{THE IMPACT OF THE EUROPEAN COURT OF JUSTICE'S PRACTICE}

The principle of legality in criminal law is brought by the Court of Justice, based on the constitutional provisions of the European countries and Article 7.1 of the ECHR. However, it should be said that decision-making, based on the constitutional provisions of EU countries, has served more in practical ways in solving issues that have been brought for consideration. Beyond that, the practical effects has played a decisive role in the Article 7.1 of the ECHR and the broad and consolidated practice of the ECHR.

However, this context brings to light a decision of the Court of Justice which stresses that the "principle of legality" is an element of the principle of the clarity of the norm: it also requires that the legal rules of the European Community countries should be clear and precise, except it is a constitutional principle of EU countries. It is also a principle described in the Article 7.1 of ECHR (The case T-279/02).

In some cases, the Court of Justice does not accept this principle. This is based on the demands put forward by the legitimate parties, affirming the 
view that the principle of allowing favorable retrospective power is an internal matter that is observed by judges (Armone, 2010). Therefore, the Alain case (The case C-341/94), states that if an initial conduct contrary to the European Community rules, and consequently to domestic law, it may be recalculated based on the function of the criminal law by a judge in cases when the circumstances of fact or the law have been changed. "In this case, retraining should not be understood as making a new legal status but withdrawing the charge or dismissing the case for lack of fact."

In adddition, Mr. Alain had declared that during the year 1985 to 1986, he imported goods from the Yugoslav Republic to France, when in fact these goods were imported from the Democratic Republic of Germany. At that time, it was not part of the rules regarding the free movement of the goods with the aim of avoiding taxes. The French authorities started a criminal proceeding against Mr. Alain, accusing him for the criminal offence of not "declaring the prohibited goods". During the proceeding in 1990, the rules regarding the free movement of the goods were applied even in the German Democratic Republic. This was as a result of its union with the German Federal Republic (the fall of the Berlin Wall). In this decision, the Court does not deny the fact that Mr. Alain has committed a criminal offence because of his false testimony, but if he had done this after the union of the two parts of Germany, his act would not be considered as a criminal offence at all. Bearing these things in mind, the Court of Justice forces the local Court (the Court of the inner system) to apply favorable rates (mitigation measures).

Also, in the case of Saeti and Frediani, the court of justice held that it was not competent to apply domestic law in order to bring the effects of the changes in favored domestic norms that determine the decriminalization of the criminal offense (Hoxha, 2013). The case that is being discussed concerned the two persons quoted above, who had executive positions at an oil refinery. They are accused of the criminal offense of using "Coke di Petrolio" "Carbon mass that is taken as a sub product of a certain refining process and is used for gas extraction" (Enciclopedia della Scienza e della Tecnica, 2008). This action at that time in the Italian State was a criminal offense, because its use was prohibited by EU directive 75/442. After the proceedings have been initiated, this Directive changes. This does not stop the application of this process but permits it. On the request of the legitimate subject, it was argued that the person in question could no longer proceed on this fact. This is because, given the changes made to the directive, this act did not constitute a criminal offense. However, the Court held that it was not within its competence to express on this fact, since the interpretation of international law is the competence of the courts of the ordinary system (The case C-235/02). 


\section{THE TOMBESI ISSUE REGARDING THE APPLICATION OF THE PRINCIPLE OF LEGALITY}

The Tombesi issue is the object of interpreting the notion of rejection in relation to the European Union Directive 75/442. From a chronological point of view, the first issue under consideration comes from the pre-trial proceedings made by the Tern and the Court (The procedure C-304/94 \& the procedure $C$-342/94). In this case, the defendants were charged with the criminal offense of "transportation, unloading, and storage of unauthorized waste". The defendants alleged that they could not be prosecuted for the criminal offense because the case which, according to the directive, was forbidden to be transported was made lawful under domestic law. Thus, the defendants sought the application of the retrospective power of the favored criminal law because their action was no longer a penile act.

Furthermore, faced with such a fact where the domestic legislation after the amendments permitted the transportation of this case and international law specifically to the said directive, which prohibits it, the court suspends the case and addresses the court of justice for interpretation of that fact. This is in the sense that when internal law changes, as a result, a given fact no longer constitutes a criminal offense. Thus, when such a change contradicts international law, can the principle of allowing retrospective power be applied when favoring the defendant?

Regarding this issue, the Court of Justice in its decision argues that "even if we are faced with a violation of international norms through the changes that are under the laws, the right of EU countries in cases where the defendant is not favored, cannot apply the latter by his burdened position in the process. This is because it relates to the principle of the legality of the sentence, where an individual may be convicted of an act if the fact constitutes a criminal offense under the provisions of the law of the country. The second argument put forward by the Court of Justice is that directives cannot be applied directly where domestic law is inconsistent with them, and when it (the directive) imposes criminal liability or aggravates it at a time when domestic law does not foresee it as a criminal offense. This, however, is because directives cannot produce effects for specific subjects or predefined names (Sentence of the case C-343/98).

Also, in support of the foregoing arguments, the Court of Justice in another case, known as the Niselli case, accepts the claims of the lawyer as to the non-direct application of the directive when it affects the position of a person accused of committing a criminal offense. This (lawyer) emphasized that: "The direct application of the directive has no effect in cases when it defines criminal responsibility when domestic law no longer provides for such as at the time of action, because internal law is autonomous from the directives. This means that "it is sufficient to repeal a rule that once brings 
criminal responsibility to an individual at a time when the directives envisage such a criminal act. Also, the basis of criminal liability shall be domestic law and not internationally. However, in cases where domestic law provides for an act as a criminal act but an international act does not tally, the directive will make direct application. What is noteworthy is the fact that the court does not comment on the argument made by the lawyer that "the directive has direct application in cases where the defendant favors".

\section{AFFIRMATION OF THE PRINCIPLE OF LEGALITY IN THE BERLUSCONI CASE (Cause Riunite C-387/02)}

In the Tombesi and Niselli case, we saw how the European Court of Justice argues that the norms of Community law do not have a direct impact on the criminal liability of a subject as long as its action at the time of trial in the domestic legal system does not constitute a criminal offense of the community right. However, what is the legal situation in the Berlusconi case? In the present case, Mr. Berlusconi was prosecuted for criminal offenses in the field of commercial companies, specifically "The criminal offense offalsifying balances". At the time of his trial, he intervenes in the Italian criminal code, not considering this as a criminal offense, and therefore it is seen as unpunishable. Under such conditions, Milan's judges suspend the process and send the case for interpretation of domestic law in relation to European community norms regarding their compliance with the European Court of Justice. The dissatisfaction of the Italian judges is concerned with the compatibility of the new standards with the directives on companies' law imposing on Member States the provision of effective, proportionate, and dissuasive penalties for false accounting works (Directives I, IV and VII in about the companies).

Under these conditions, the Milan Judges argued that in this principle, there is a discrepancy in the domestic legislation "Criminal Code with respect to the criminal offense quoted above" with the acts of the European Union, namely directives in the field of commercial companies. This is with the reaffirmation that at the time the Italian lawmaker were decriminalizing the criminal offense of counterfeiting of balances, there existed an obligation arising from the EU directives where States should provide effective and punitive punishments for criminal offenses of false accounting, by making a repeal in violation of these acts. In the present case, Mr. Berlusconi's lawyer presented to the Luxembourg Court the arguments which he had put forward in the proceedings against Niselli and Tombesi. He however did this in more detail by making part of the reasoning as the decision of the court on those two subjects in which arguing the lack of power of community law is seen in cases when it brings direct criminal responsibility to certain individuals (Defense Counsel Kokott who also defended Niselli and Tombesi). 
In the present case, the Luxembourg Court abruptly maintains a different attitude from that held in the Tombesi and Niselli case where the case is identical in the element such as: the facts of the offense at the time when they were punished under national law; there is a change of the case favorably for the accused, which is in accordance with the previous legislative continuity; where his action at the time of the trial was no more criminal offense. Meanwhile, this is with regard to the acts, not the fact, specifically, of the relationship with the community law. In this case, the contrast between the internal standard overrides a directive and no direct effect was reported. This was precisely the fact that lawyer Kokotti presented the same conclusions and excuses as in the Tombesi and Niselli case. In its decision, the Luxembourg Court argues: "where there is a link between domestic acts and acts of the European Community, the retroactive application of the preferential criminal law is justified only if the priority of Community law is guaranteed; this is so that the objectives of the legislature community and the national legislature (revised) is in compliance with the requirements of Community law. If not, the national judges should ensure the application of the provisions of Community law, leaving aside national provisions even if it concerns more favorable criminal laws. This position of the Luxembourg court is undoubtedly a legal remedy contrary to the very nature of the directives which have no binding effect on the States parties but have advisory recommendations. Also, from the point of view of the conclusions, this court argument contradicts its own practice which was also apparent in the Tombesi and Niselli case that international acts do not have direct effects on certain individuals. Thus, these effects subsequently bring criminal responsibility to these individuals.

\section{The European Convention on Human Rights on the Principle of "Favor Rei" (Article 7/1)}

In addition to the codification of human rights and fundamental freedoms at the world level (made through the Universal Declaration of Human Rights and through the Charter of Civil and Political Rights), which are the main notions of Favor Rei, there is also a legal protection of these rights at European level, through the "European Convention on Human Rights". The main role of such a legal protection is the "Council of Europe", which in 1950 made it possible to establish the European Convention on Human Rights (Convention signed in Rome on 4 November 1950). The European Court of Human Rights through the diversification of decisions, deep analysis, and the disclosure of substantive arguments has consolidated not only its court practice but also its domestic legal systems.

This Convention makes it possible to establish a postulate that "fundamental rights and freedoms cannot be protected only by an internal legal system". This is because in most cases, it is precisely the domestic legal 
system through the force of state authority that violates human rights and fundamental freedoms. In this context, it was considered reasonable to create an international instrument that would make it possible to guarantee by restoring in place the rights violated or alleged to have been violated in an internal court case where it is precisely the case of the "European Court for Human Rights ", otherwise known as the "Strasbourg Court ". This court acts as a guarantor of human rights at the European level, which through its activity offers a panorama or provoke a uniform application of the legal norms of this convention, certainly based on the specifics of each case.

\section{LACK OF THE FAVOR OF REI (ABOLITO CRIMINIS) IN THE ECHR}

As is also apparent from the preamble to Article 7 of the Convention, there is a non-existent projection of the application of the criminal law even for offenses committed contrary to the criminal law changes when the defendant is favored by the changes made. The ECHR in its case-law has forbidden the application of Article 7 of the ECHR, when the criminal law favors the defendant (full abrogation). Also, this court in general sanctions the principle of legality "that an act is punishable when it is foreseen before it is committed and that the law foresees a sanction, imposing the prohibition of so-called analogue" in malam partem " and that a crime should be clearly and precisely defined in the law (Kokkinakis C.V. Greece, 1993).

Article 7 of the Convention is disciplined by the phenomenon of "Criminal Law Action in Time", otherwise known as the principle of legality configured with the term "No Penalty without a Law". This provision prohibits the application of the criminal law for acts which at the time of their commission did not constitute a criminal offense under domestic or international law, but by elaborating the fact that it is permissible to apply the criminal law in time for criminal offenses committed before the changes that the law has undergone when the latter favors its author (Salihi, 2016; Muçi, 2010). The principle of favor is not explicitly stated by the ECHR, but the bodies authorized by the Convention have enabled the affirmation of a favorable rate based on concrete cases, thus setting general standards for subsequent cases.

Regarding international acts, the constitutional lawmaker has made a trivial guarantor for international acts, defining what their strength is, how the reports of domestic acts are, and how their incorporation is. Thus, referring to Article 5 of the Constitution, Articles 116 and 122, the above trinomial is highlighted (Albanian Constitution, Article 122). Article 5 of our constitution identifies the value of international acts and the effects of adopting an international act by making it part of the domestic legal system. This states that international acts are mandatory for implementation by Albanian 
institutions as well as the side of the Courts that make up the justice system in the Republic of Albania. Their compulsory nature is closely related and reflected by the introduction of legal norms made by Article 116 of the Constitution, which in the view of the contradiction of domestic and international norms gives priority to international acts for implementation (Albanian Constitution).

In the interpretation of these constitutional provisions, the Constitutional Court of the Republic of Albania is also pronounced, which in its decisions indicates the nature of international acts. In its ruling, this Court states: "As stated in some of its decisions, the European Court of Human Rights, the guarantee embodied in Article 7 of the Convention, is an essential element of the rule of law. This guarantee must be interpreted and applied in such a way as to provide effective safeguards against prosecution, guilty plea, and arbitrary punishment" (Decision no. 14, 17.04.2007).

Furthermore, in its reasoning, this Court states: "According to Article 29/3 of the Constitution of the Republic of Albania, the favorable criminal law has retroactive effect". This important constitutional principle is explicitly mentioned in Article 15/1 of the UN International Covenant on Civil and Political Rights, ratified by the Republic of Albania on 04.01.1992.

In another decision which highlights the relationship between international and domestic acts, not limited to the notion of favor, the Constitutional Court states: "In conclusion, following the foregoing reasoning, the Court considers that in the process developed by the courts of ordinary jurisdiction, the right to a due legal process has been violated in the sense of Article 42 of the Constitution and Article 6 of the ECHR."

The Albanian Constitutional Court, by its Decision 6/2006, states: "According to Article 116 of the Constitution, the Convention as an international agreement ratified by law in the hierarchy of legal norms ranks immediately after the Constitution. Consequently, it occupies an important place in domestic law and becomes enforceable for each state, for all state bodies including here and the courts of each level as well as the bodies that enforce their decisions. The guarantees of the Convention affect the interpretation and protection of the individual's fundamental rights and freedoms expressed by the Constitution of the Republic of Albania. In addition, the Constitutional Court notes that the text of the Convention and the case law of the Strasbourg Court serve to make constitutional interpretation and to determine, on a case-by-case basis, the boundaries of fundamental constitutional rights. This position of the Convention comes as a result of the commitment of the Albanian State to provide a guaranteed protection of human rights and fundamental freedoms. Another important aspect relates to the obligations deriving from the case law of the Strasbourg Court for the parties to the proceedings because, under Article 41 of the Convention, the 
Contracting Parties, by ratification of the Convention, are obliged to ensure the compatibility of the legislation internal to the Convention. In addition, the practice of this Court places importance on the guiding values of its jurisprudence for the Albanian courts as well." (Decision of the Constitutional Court of the Republic of Albania No. 6/2006)

\section{Conclusion}

Thus, as noted above, the analysis of International Act such as the European Convention on Human Rights, the practice of the European Court of Justice, the domestic law such as the Constitution of the Albanian Republic, and the practice of the Constitution Court of Albania determine that the principle of the Legality has an important place for the well-functioning of the justice system, particularly, by the Courts.

Also, the analysis of this principle determine that it is not only an inevitable principle in criminal law but as well as a guaranty and an absolute undeniable element in the determination of criminal offenses.

\section{References:}

1. Albanian Constitution Approved by the Law Nr. 8417, datë 21.10.1998.

2. Carlassarre, L. (1990). Voce Legge (riserva di), in Enc. Giur., XVIII.

3. Council Directive of 15 July 1975.

4. CGCE, 3 maggio 2005, Cause Riunite C-387/02.

5. Decision of the Constitutional Court of the Republic of Albania no. 6/2006.

6. Decision of the Constitutional Court of the Republic of Albania no 14, dated 17.04.2007.

7. Decision of 27 October (procedure C-304/94), 14 November (procedure C-342/94).

8. European Convention on Human Rights signed in Rome on 4 November 1950.

9. Enciclopedia della Scienza e della Tecnica, 2008, http://www.treccani.it/enciclopedia/coke-di- petrolio_\% 28Enciclopedia_della_Scienza_e_della_Tecnici-a\%29/)

10. Fabrizio Ramacci, F. \& Corso di Diritto Penale, I. (1991) Principi Costituzionali e Interpretazione Della Legge Penale, Giapichelli Editore, Torino, pg. 13.

11. Fiandaca G., Musco E., Diritto Penale., Parte Generale., \& Zanichelli (2014). Pg.55, ISBN8808421252.

12. Fiandaca, G., Musco, E., Diritto Penale, Parte Generale, IV ed., \& Bologna (2001). pg. 48. 
13. Giovagnoli, R. (2008). studi di Diritto Penale "Il principio di Riserva di Legge" Giuffre Editore, Anno, pg.5. ISBN : 8814137838.

14. Giovanni, A. (2010). Il Principio di Retroattività della Legge Penale più Favorevole come Diritto Fondamentale nella Giurisprudenza Multilivello in www.europeanrights.eu; Anno 2010.

15. Hoxha, D. (2013). Doctoral Thesis, Faculty of Law, Tirana University "Koha në të Drejtën Penale".

16. Ismali, H., Hoxha, A., \& Panda, I. (2011). Criminal Procedure.

17. Mantovani F., Diritto Penale., Parte Generale., \& Zanichelli (1992).

18. Pietro Giuseppe, G.P. (1972). Il principio "nullum crimen sine lege" nella Costituzione Italiana, Giuffrè, Milano, pg. 31.

19. Salihi (2010). "Criminal Law-General", Botuar nga Universiteti i Prishtinës, viti 2016, Muci Sh. "Criminal Criminal Law, General Criminal Law Criminal-General Party" viti.

20. The decision of April, 05, 2006, Degussa AG, the case T-279/02, pg. 66.

21. The Decision of February 23, 1995, the case C-341/94.

22. The case C-235/02, You can find it on this link: http://www.curia.europa.eu.

23. The Sentence of the case C-343/98, Collino e Chiappero 14 Septembre 2000 ;

24. ECHR, 25 May 1993, Kokkinakis C.V. Greece. 